\title{
Simplified Business Information: a technical position in accounting and taxation
}

\author{
Fátima David $^{1}$, Rute Abreu ${ }^{1}$ and Francisco Carreira ${ }^{2}$ \\ ${ }^{1}$ Polytechnic Institute of Guarda, Av. Dr. Francisco Sá Carneiro, 50, 6300-559 Guarda, Portugal \\ ${ }^{2}$ Polytechnic Institute of Setúbal, Campus do IPS, Estefanilha, 2914-503 Setúbal, Portugal \\ \{sdavid@ipg.pt,ra@ipg.pt,francisco.carreira@esce.ips.pt
}

Keywords: Simplified Business Information, Accounting, Taxation.

Abstract: This paper is focused on Simplified Business Information (SBI) - "Informação Empresarial Simplificada" (IES), hereinafter IES, in the accounting and taxation context. IES is a new way for firms to deliver business information online to public services, by using a totally dematerialized procedure. The theoretical framework of this paper is based on accounting and taxation information that evaluate the impact of the online submission of the IES files, since firms fulfil, at once, four different obligations: 1) Deposit of annual accounts in the Commercial Registry of the Ministry of Justice; 2) Delivery of annual fiscal declaration to the Ministry of Finances and Public Administration; 3) Delivery of annual information to National Statistics Institute for statistical purposes; and 4) Delivery of information to the Portuguese Central Bank. Thus, the paper attempts to provide an understanding the adoption of the dematerialized procedure, because the increasing of a firm's activity and changes in its accounting and taxation environment require new attitudes of disclosure information, as a key factor that negatively and positively influences the accounting and taxation regime, particularly on Portugal.

\section{INTRODUCTION}

The Simplified Business Information (IES) system was thus set up via Decree-Law $n^{\circ} 8 / 2007$ of January 17 (MJ, 2008). As the authors consider the IES system as an example of good practice within the European Statistical System, this paper attempts to provide an understanding the adoption of the dematerialized procedure, because the increasing of a firm's activity and changes in its accounting and taxation environment require new attitudes of disclosure information, as a key factor that negatively and positively influences the accounting and taxation regime, particularly on Portugal.

IES is a new way for firms to deliver business information online to public services, until the end of June or of the sixth month subsequente to the tax year end (for firms with a tax year diferente from the calendar year), by using a totally dematerialized procedure, since firms fulfil, at once, four different obligations: 1) Deposit of annual accounts in the Commercial Registry of the Ministry of Justice; 2) Delivery of annual fiscal declaration to the Ministry of Finances and Public Administration; 3) Delivery of annual information to National Statistics Institute for statistical purposes; and 4) Delivery of information to the Portuguese Central Bank.

The literature of the information systems recommends that this system must exploit the new Information and Communication Technologies for competitive advantages of firms, develop new architectures and creative environments of the accounting and taxation information, exploit direct and indirect management resources and align the investments and costs with the business goals (Earl, 1993; Porter, 2001; Chen et al, 2010).

The structure of the paper is organized as follows. Section 2 gives an overview of the Portuguese regulation of the Simplified Business Information. Section 3 argues the accounting and taxation information disclosure through the dematerialized procedure. Finally, the section 4 presents the conclusions and makes some recommendations.

\section{IES REGULATION}

The tax system in Portugal is administered by the Portuguese Tax Authority (Autoridade Tributária e 
Aduaneira) and usually the Portuguese tax year follows the calendar year, closing 31 December.

A brief overview of the Portuguese tax system shows: direct and indirect taxes with the major emphasis on those relating to business (Corporate Income tax (IRC); Personal Income tax (IRS); taxes on Assets (IMI and IMT); taxes on Expenditure (VAT, IEC, ISV); Stamp Tax; and the Tax Benefits (AICEP, 2012).

In this context appears the Simplified Business Information (IES) system that includes information about the follows taxes: Corporate Income tax (IRC); Personal Income tax (IRS); tax on consumer spending, i.e., Value Added Tax (VAT); and Stamp Tax.

According AICEP (2012), the Corporate Income tax (IRC) is, among other things: charged on an undertaking's income and not on its assets; direct because it is charged on the basis of a direct statement of capacity to pay; periodic because as a rule tax is payable annually, for successive tax periods; proportional because the rate is constant, irrespective of the value of the taxable income; general because it affects all income obtained by corporates. The Corporate Income Tax Code (CIRC) was approved by Decree-Law $\mathrm{n}^{0} 442-\mathrm{B} / 88$ of 30 November (MF, 1988b) and entered into force on 1 January 1989.

The Personal Income tax (IRS) is based on constitutional principle that tax must be progressive (article 104 of the Constitution of the Republic of Portugal), with the object of reducing social inequality. IRS is payable on the annual total value of all personal income, irrespective of source, form and place of realisation. The tax base is calculated by adding together the gross income in each one of the 6 categories: paid employment income (A); business and professional income (B); capital income (E); real property income (F); asset income and capital gains $(\mathrm{G})$; and pensions $(\mathrm{H})$. The Code of Personal Income Tax (CIRS) approved by DecreeLaw $\mathrm{n}^{\circ} 442-\mathrm{B} / 88$ of 30 November (MF, 1988a) and entered into force on 1 January 1989.

The Value Added Tax (VAT), approved by Decree-Law n $n^{\circ} 394-B / 84$ of 26 December (MFP, 1984) and entered into force on 1 January 1986, is a general tax on consumption (becoming payable every time an article of merchandise or a service is supplied), in multi-phase form, as it is paid at all points on the economic circuit without cumulative effects.

The Stamp Tax is an indirect tax whose legal basis is the Stamp Duty Code approved by Law $\mathrm{n}^{\circ}$ 150/99 of 11 September (AR, 1999). This tax is payable on all deeds, contracts, documents, securities, paper and other acts in the law specified in the General Table, including transfers of goods and property without valuable consideration.

Following this, IES is the electronic submission of information of accounting, fiscal and statistical natures that firms have usually to remit to the Ministry of Justice, the Ministry of Finances and Public Administration, National Statistics Institute and the Portuguese Central Bank, having the advantage of simplifying the reporting process of firms to different entities by concentrating all reports in just one (KPMG, 2009). As a consequence, these institutions are no longer allowed to directly request the annual data included in IES.

IES is regulated by several legislation that beginning with the approval of the Decree-Law ${ }^{0}$ 8/2007 of January 17 (MJ, 2008) allows firms to fulfil four reporting obligations, to four distinct public entities, through one single electronic submission and at one moment in time.

To meet this challenge, Executive Order $\mathrm{n}^{0}$ $562 / 2007$ of 30 April (MJ, 2007), that amends Executive Orders $n^{\circ} 657-\mathrm{A} / 2006$ of 29 June (MJ, 2006a) and $n^{\circ} 1416-\mathrm{A} / 2006$ of 19 December (MJ, 2006b), establishes the terms and charges for the automated register and electronic reporting of accounts under the simplified business information, and regulating access to the annual account database.

So, are subject to deliver the IES: commercial companies; civil law companies having a commercial form; limited companies; public entities; companies established abroad and representation permanently in Portugal (in these cases the accounts relating to the present permanent representation itself and not to the foreign company); individual establishments with limited liability; associations; foundations; sole traders; and cooperatives.

On one side, Executive Order $\mathrm{n}^{\circ} 499 / 2007$ of 30 April (PCM, 2007), amended Executive Order $\mathrm{n}^{\circ}$ 245/2008 of 27 March (PCM, 2008), institutes the rules on the reporting of simplified business information by electronic means.

On the other hand, the forms for the annexes to the statement on IES were approved by Executive Order $n^{\circ}$ 208/2007 of 16 February (MFAP, 2007a), amended Executive Orders $n^{\circ} 8 / 2008$ of 3 January (MFAP, 2008), $n^{\circ} 333-\mathrm{B} / 2009$ of 1 April (MFAP, 2009a), no 64-A/2011 of 3 February (MFAP, 2011a) and $n^{\circ}$ 26/2012 of 27 January (MFAP, 2012).

The actualization of news forms for the IES annexes is a result of legislative changes introduced in under the tax code, such as the CIRS and CIRC. 
Specifically, this last law has been subjected to multiple amendments since it was first published being the Decree-Law $n^{0}$ 159/2009 of 13 July (MFAP, 2009c) the last one, that adapted the CIRC to the international accounting rules adopted by the European Union and the new national Accounting Harmonisation System (AHS) - "Sistema de Normalização Contabilística” (SNC) approved by Decree-Law n ${ }^{\circ}$ 158/2009 of July 13 (MFAP, 2009b).

More recently, the Law $n^{0} 35 / 2010$ of 2 September (AR, 2010), institutes a special simplified regime of accounting standards and information applicable to micro entities. And the Decree-Law $n^{\circ}$ 36-A/2011 of 9 March (MFAP, 2011b), approves the accounting standard regime for micro entities and non-profit sector entities and implements certain disclosure requirements for medium-sized companies and also regarding the obligation to prepare consolidated accounts.

The conceptual framework of the accounting and taxation normative suggest that a significant improvement exists actually, in relation to the international comparability of practices as well as in relation to the largest level of purification of the concepts used in the accounting and taxation system (David \& Gallego, 2007). According to Regulation (EC) $n^{\circ} 1606 / 2002$ of 19 July 2002 (EC, 2002), the EU member states altered its understanding of the accounting system and consequently of the fiscal system, with the main objective of satisfy the users' needs, for opposition to the preparation and presentation of the annual accounts to Fiscal Administration.

\section{INFORMATION DISCLOSURE}

According to Nabais (2010), the taxpayer in addition to accounting practice that allows you to make the financial and economic analysis must also have tax purposes. So, in this context, the taxpayer has to submit the financial statement and taxation information.

Simplified Business Information (IES) represents a concrete measure to simplify reporting and, thus, to reduce firms' reporting burden in the context of their annual accounts' disclosing obligations. From the viewpoint of the Portuguese Central Bank, the success of IES is due to the excellent institutional cooperation among the public entities involved in this initiative (BdP, 2008).

Neves (2008) states that the success of the IES system is centred on: political support as the key; entities actively involved; involvement of the enterprises; statistics Portugal commitment not collect data more than once; and data quality was improved.

IES makes it simpler for firms and public entities receiving the data. In the past, firms were obliged to remit nearly the same information about their annual accounts to four different public entities in four different moments in time and according to four different formats (see Fig. 1):

- the legal deposit of accounts, on paper, was to be provided to the commercial registers of the Ministry of Justice;

- the annual declaration on accounting and taxation data had to be sent, electronically, to the Ministry of Finances and Public Administration;

- statistical information derived from accounting data for a subset of firms had to be reported to National Statistics Institute of Portugal; and

- statistical information derived from accounting data for a subset of firms had to be submitted to the Portuguese Central Bank.

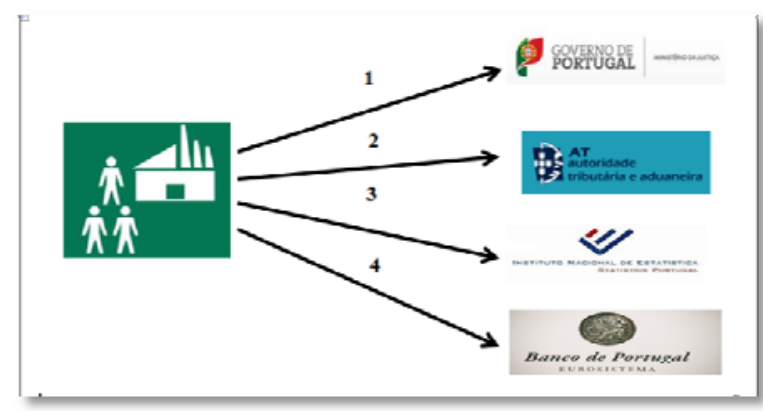

Figure 1: Reporting before IES implementation.

In the present, all the firms' information has to provide about their annual accounts is submitted just once, in a single electronic form (see Fig. 2). At the same time, public entities may have access to a complete set of duly certified business information concerning all firms (BdP, 2008). As a result, overall social costs are reduced and a better knowledge of the situation of firms and economic and financial context is made available.

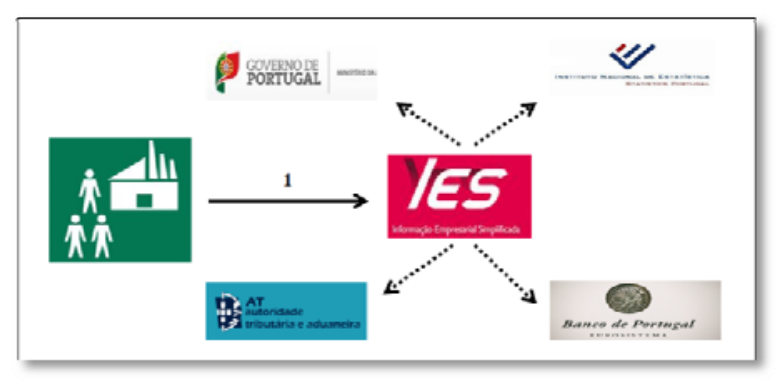

Figure 2: Reporting after IES implementation. 
The areas that most benefit with this new system were the production of statistics and the legal deposit of accounts. Indeed, all firms (mainly nonfinancial firms) are now covered and superior data quality is achieved, while with the deposit of accounts, the number of firms registered increased strongly. Table 1 based on BdP (2008) database summarizes the main advantages of IES for the Portuguese Central Bank and the Ministry of Justice.

Table 1: Situation before and after IES implementation.

\begin{tabular}{|c|c|c|}
\hline $\begin{array}{c}\text { Portuguese Central } \\
\text { Bank }\end{array}$ & Before & After \\
\hline Firms (adherence) & $5 \%$ & $100 \%$ \\
\hline Formats & Mostly automatic & Totally automatic \\
\hline Timeliness & $10 / 12$ months & 6 months \\
\hline Level of detail & +600 items & +1800 items \\
\hline Ministry of Justice & Before & After \\
\hline Firms (adherence) & $23 \%$ & $100 \%$ \\
\hline Formats & Totally manual & Totally automatic \\
\hline Points of access & $\begin{array}{c}312 \text { commercial } \\
\text { registry offices }\end{array}$ & $\begin{array}{l}\text { Annual accounts } \\
\text { database - online }\end{array}$ \\
\hline Monitoring & $\begin{array}{l}\text { Practically } \\
\text { impossible }\end{array}$ & 100\% possible \\
\hline System & $\begin{array}{c}\text { One of the most } \\
\text { old-fashioned }\end{array}$ & $\begin{array}{c}\text { One of the most } \\
\text { advanced }\end{array}$ \\
\hline
\end{tabular}

Following this, agreeing with BdP (2008), with the IES system are expected improvements in what concerns the production of statistics, specifically:

- an accurate knowledge of the economic and financial situation of non-financial firms, given that a comprehensive set of information for all existing firms will be gathered through the new system;

- the information obtained can be used to increase the quality of existing statistics. For example, by cross-checking IES individual data with data resident in already existing databases;

- IES can be used as a basis for defining the reporting population in specific surveys, and contribute to the extrapolation of certain phenomena;

- the production of "final" statistics can be performed directly, especially because the total population reports.

With this information, the State will create a database that will allow later to any duly registered user, request a certificate with the desired information (Lemos, 2007). This measure, as well as making the simplification of the acts of business registration and related deeds, and the dematerialization of documents and tax procedures, and initiatives such as the "Empresa na Hora", is part of the Simplex Programme, introduced in March 2006 by the Government through the use of new information technologies (MFAP, 2007).

For the different services of the public administration with responsibility on IES system the advantages are reducing the burden associated with purely bureaucratic tasks and release of human and material resources for other activities, as well as the possibility of statistical information now concerns the universality enterprises, which will allow an analysis closer to the national economy.

In general, with the generalization of the IES system, the Portuguese economy is more competitive because it becomes more transparent and there is more information on the Portuguese market, as well as the information to investors becomes more present, because it is available for consultation soon and the statistical information on the accounts shall cover all Portuguese companies, which allows a more accurate and complete picture of the national economy for investors.

\section{CONCLUSIONS}

The authors agree with Treacy et al. (2008), who consider the Simplified Business Information system as a good example of innovation and coordination in the European Statistical System, in general, and in the Portuguese Statistical System, in particular, reducing response burden while improving the coverage of structural business statistics.

The Simplified Business Information are not welcomed, enthusiastically, despite the benefits it brings, because it concentrates information about several areas: accounting, taxation and corporate governance, improve the tax services and the accountant work productivity, allow to plan the taxation of each firm and oblige to communicate this to the Autoridade Triburária e Aduaneira, decrease the tax evasion and the reduction of bureaucracy.

Despite, all the advantages and disadvantages, the technical position in accounting and taxation of the SBI oblige the accountant to become increasingly specialised and his strategic involvement well beyond numbers to truly provide consultancy services for all the options that could be made in this information document. Indeed, with this document is possible to produce a corporate finance report, corporate recovery or insolvency process, forensic and litigation activities.

The impact of technology is becoming increasingly evident that the traditional taxation work undertaken by accountants because the 
Simplified Business Information demands professional skills and competences on the new Information and Communication Technologies.

The main advantages of IES adoption for firms are presenting in a single moment accounting data for taxes, legal and statistical purposes, giving political support for better coordination among institutions; no increase of burden financing and insurance enterprises; accountants could provide all data from their systems once the Software was adapted.

In conclusion, although the IES does not aim the payment of taxes, since the only tax obligation is the delivery of the Annual Statement, it came facilitate and reduce the costs of compliance with legal obligations of firms as well as improves financial analysis and system supervision by public entities.

\section{ACKNOWLEDGEMENTS}

The authors wish to thank José Ángel López Pérez of Universidad de Seville (Spain). Also, the current version is a publication supported by the Project PEst-OE/EGE/UI4056/2014a UDI/IPG, finance by the Fundação para a Ciência e Tecnologia. Ideas expressed in the article are those of the authors and should not be attributed to any organization.

\section{REFERENCES}

Agência para o Investimento e Comércio Externo de Portugal (AICEP, 2012). Portuguese Tax System. Lisboa: AICEP.

Assembleia da República (AR, 1999). Lei no 150/99, aprova o o Código do Imposto do Selo. Diário da República, 213, I Série, 11/09: 6264-6275.

Assembleia da República (AR, 2010). Lei ${ }^{\circ}$ 35/2010, aprovou a simplificação das normas e informações contabilísticas das microentidades. Diário da República, 171, I série, 02/09: 3857.

Banco de Portugal (BdP, 2008). Simplified Reporting: inclusion of IES in the Statistics on Non-Financial Corporations from the Central Balance-Sheet Database. Statistical Bulletin, Supplement 1 (May): 145.

Chen, D., Mocker, M., Preston, D. e Teubner, A. (2010). Information systems strategy: reconceptualization, measurement, and implications. MIS Quarterly, 34 (2), 233-259.

David, F., Gallego, I. (2007). Corporate Income Tax: A European Context. Estudos e Documentos de Trabalho da Escola Superior de Tecnologia e Gestão da Guarda, 6 (2): 1-15.
Earl, M. (1993). Experiences in strategic information systems planning. MIS Quarterly, 17 (1), 1-24.

European Community (EC, 2002). Regulation (EC) $\mathrm{n}^{0}$ 1606/2002 of the European Parliament and of the Council of 19 July 2002 on the application of international accounting standards. Official Journal, L 243, 11/09: 1-4.

KPMG (2009). Tax Guide Portugal 2009. Lisboa: KPMG $\&$ Associados.

Lemos, S. (2007). A Informação Empresarial Simplificada (IES). NewsLetter RVR, 1 (Abril): 1-2.

Ministério da Justiça (MJ, 2006a). Portaria n. ${ }^{\circ}$ 657A/2006, regula o regime da promoção electrónica de actos de registo comercial e cria a certidão permanente. Diário da República, 242, I Serie, $2^{\circ}$ Suplemento, 19/12: 8500-(38)-8500-(42).

Ministério da Justiça (MJ, 2006b). Portaria n. ${ }^{\circ}$ 1416A/2006, aprova o Regulamento do Registo Comercial. Diário da República, 124, I-B Serie, Suplemento, 29/06: 4632(2)-4632(6).

Ministério da Justiça (MJ, 2007). Portaria n. ${ }^{\circ}$ 562/2007, altera as Portarias n. ${ }^{\circ}$ 657-A/2006, de 29 de Junho, e 1416-A/2006, de 19 de Dezembro, fixando os termos e a taxa devida pelo registo automático e electrónico da prestação de contas, no âmbito da IES e regulando o acesso à base de dados das contas anuais. Diário da República, 83, I Serie, 30/04: 2918-2921.

Ministério da Justiça (MJ, 2008). Decreto-Lei no 8/2007, cria a Informação Empresarial Simplificada (IES). Diário da República, 12, I Serie, 17/01: 378-388.

Ministério das Finanças (MF, 1988a). Decreto-Lei n. ${ }^{\circ} 442-$ A/88, aprova o Código do Imposto sobre o Rendimento das Pessoas Singulares (IRS). Diário da República, 277, I Série, $2^{\circ}$ Suplemento, 30/11: 4754(2)-4754(35).

Ministério das Finanças (MF, 1988b). Decreto-Lei n. ${ }^{\circ}$ 442-B/88, aprova o Código do Imposto sobre o Rendimento das Pessoas Colectivas (IRC). Diário da República, 277, I Série, $2^{\circ}$ Suplemento, 30/11: 4754(38)-4754(71)

Ministério das Finanças (MF, 2012). Portaria no 26/2012, aprova os novos modelos de impressos relativos a anexos que fazem parte integrante do modelo da IES. Diário da República, 20, I Série, 27/01: 492-493.

Ministério das Finanças e da Administração Pública (MFAP, 2007a). Portaria n. ${ }^{\circ}$ 208/2007, aprova o modelo declarativo da IES e respectivos anexos. Diário da República, 34, I Série, 16/02: 1192-1221.

Ministério das Finanças e da Administração Pública (MFAP, 2007b). Stability and Growth Programme 2007-2011. Lisboa: MFAP.

Ministério das Finanças e da Administração Pública (MFAP, 2008). Portaria n. ${ }^{\circ} 8 / 2008$, aprova os novos modelos de impressos relativos a anexos que fazem parte integrante do modelo declarativo da IES. Diário da República, 2, I Série, 03/01: 66-82.

Ministério das Finanças e da Administração Pública (MFAP, 2009a). Portaria n. ${ }^{\circ}$ 333-B/2009, aprova os novos modelos de impressos relativos a anexos que fazem parte integrante do modelo declarativo da IES. 
Diário da República, 64, I Série, 01/04: 2040(2)2040(16).

Ministério das Finanças e da Administração Pública (MFAP, 2009b). Decreto-Lei n. ${ }^{\circ}$ 158/2009, aprova o Sistema de Normalização Contabilística e revoga o Plano Oficial de Contabilidade. Diário da República, 133, I Série, 13/07: 4375-4384.

Ministério das Finanças e da Administração Pública (MFAP, 2009c). Decreto-Lei n. ${ }^{\circ}$ 159/2009, no uso da autorização legislativa concedida pelos n. ${ }^{\circ} 1$ e 2 do artigo $74 .^{\circ}$ da Lei n. ${ }^{\circ}$ 64-A/2008, de 31 de Dezembro, altera o Código do IRC, adaptando as regras de determinação do lucro tributável às normas internacionais de contabilidade tal como adoptadas pela União Europeia, bem como aos normativos contabilísticos nacionais que visam adaptar a contabilidade a essas normas. Diário da República, 133, I Série, 13/07: 4384-4448.

Ministério das Finanças e da Administração Pública (MFAP, 2011a). Portaria . $^{\circ}$ 64-A/2011, aprova os novos modelos de impressos relativos a anexos que fazem parte integrante do modelo da IES. Diário da República, 24, I Série, 03/02: 674(2)-674(30).

Ministério das Finanças e da Administração Pública (MFAP, 2011b). Decreto-Lei n. ${ }^{\circ}$ 36-A/2011, aprova o regime simplificado para as microentidades que a Lei n. ${ }^{\circ}$ 35/2010 instituiu. Diário da República, 48, I Série, 09/03: 1344(2)-1344(11)

Ministério das Finanças e do Plano (MFP, 1984). DecretoLei n. ${ }^{\circ}$ 394-B/84, aprova o Código do Imposto sobre o Valor Acrescentado (IVA). Diário da República, 297, I Série, $1^{\circ}$ Suplemento, 26/12: 3924(12)-3924(44).

Nabais, C. (2010). Prática Contabilística. Lisboa: Lidel.

Neves, C. (2008). Simplified Business Information: Improving quality by using administrative data in Portugal. Lisboa: INE.

Porter, M.E. (2001). Strategy in the Internet. Harvard Business Review, march, 62-78.

Presidência do Conselho de Ministros (PCM, 2007). Portaria n. ${ }^{\circ}$ 499/2007, estabelece as normas relativas ao envio da IES por transmissão electrónica de dados. Diário da República, 83, I Série, 30/04: 2798-2799.

Presidência do Conselho de Ministros (PCM, 2008). Portaria n. ${ }^{\circ}$ 245/2008, altera a Portaria n. ${ }^{\circ}$ 499/2007, de 30 de Abril, que estabelece as normas relativas ao envio da IES por transmissão electrónica de dados. Diário da República, 61, I Série, 27/03: 1769.

Treacy, J., Diaz Muñoz, P.. Holzer, W. (2008). Peer review on the implementation of the European Statistics Code of Practice. Lisboa: INE. 